\title{
The potential of geographical indications and Its legal protection
}

\author{
Faradila Yulistari Sitepu* \\ Doctoral Program in Law, Graduate School, Universitas Sumatera Utara, Medan, Indonesia
}

\begin{abstract}
The legal protection of Geographical Indication (GI) is given to Indonesian typical products to prevent them from being registered as overseas brands, as previously happened in the case of Toraja Arabica coffee registered by a Japanese company and the Gayo coffee by a Dutch company. With the foreign trademark registration, the products harvested from the land of Indonesia can no longer be recognized as belonging to Indonesia because they can hardly be claimed to have come from Indonesia. Therefore, it is the foreign party that will enjoy the benefits of the famous Indonesian products. Geographical indication certainly requires a legal protection. This is important so that the natural rights owned by the original holder can be guaranteed and a sense of security can be realized. A product yielded from the nature and human creativity that has distinctive features, cannot be found elsewhere, and has a reputation that can increase the competitive power of the original region should get more attention from the government, especially the local government. The legal protection of Geographical Indication does not only provide economic benefits to the right holder, but also to the geographical environment of the product origin.
\end{abstract}

\section{Introduction}

Indonesia has a diverse culture and biodiversity. The issue of geographical indication is set forth in the Trade Related Aspects of Intellectual Property Rights (TRIPs) agreement, which requires member states to draft regulations on geographical indication in order to provide a legal protection against fraudulent competitions or practices ${ }^{[1]}$. Geographical indications are governed by the Trade Related Aspects of Intellectual Property Rights (TRIPs) agreement, which requires member states to draft regulations on geographical indication in order to provide a legal protection against fraudulent competitions or practices ${ }^{[2]}$.

By ratifying the establishment approval of the World Trade Organization (WTO), Indonesia is obliged to accept WTO agreements and its attachments, including the TRIPs. The existing protection in the framework of the TRIPs, through the ratification of the States toward the establishment of the WTO, is expected to provide a systematic and sustainable international protection scheme for States that are likely to sell the geographical indication products. Indonesia is obliged to adapt its national legal framework in such a way that it complies with the degree of protection of the six types of intellectual property rights as

* Correspondent Author: faradila.yulistari@usu.ac.id 
contained in the TRIPs agreement, including protection of geographical indication into the Law No.15 of 2001 on Trademarks ${ }^{[3]}$.

TRIPs defines Geographical Indication as a sign that identifies a territory of a member country, or a region or area within the territory as the origin of the goods, in which the reputation, quality, and characteristics of the goods concerned are determined by geographical factors. Thus, the origin of a particular product which is attached to the reputation, characteristics and quality of a product associated with a particular area should be legally protected. ${ }^{[4]}$

Geographical Indication is a branch of Intellectual Property Rights in addition to patents, copyrights, confidential/secret trade information and other types of intellectual property rights. Geographical indication is a sign used for goods having a certain geographical origin and also has the quality or reputation generated by the place of origin.

The information technology is developing so rapidly nowadays that it has made the world smaller. Information can easily and quickly spread to all corners of the world. Under these circumstances, intellectual property rights are becoming increasingly important. Since the intellectual property rights act as monopoly rights that can be used to protect investments and can be transferred. But the most important aspect, when associated with the protection of intellectual work, is the legal aspect. ${ }^{[5]}$

Discussing geographical indication cannot be separated from studying trademark since Geographical Indication, under Law No.15 of 2001, is considered as one type of a trademark $^{[6]}$. There are several notions of a trade mark, one of which is defined by H.M.N Purwo Sutjipto, namely: "Trademark is a mark by which a particular item is personalized to distinguish it from other similar product". ${ }^{[7]}$

Ironically, the protection of geographical indication in Indonesia until now has not been sufficient to provide a legal protection for the potential geographical products. Internally, the number of geographical indication certificates is still relatively small compared to the potential of geographical indications. ${ }^{[8]}$ At the same time, a number of violations of Indonesia's geographical indications have externally happened such as the case of Gayo Coffee in which the trademark was claimed by a Dutch trading company as the right holder. In fact, Gayo coffee is a typical product from Nanggroe Aceh Darussalam, Indonesia. The Dutch company (Holland Coffe B.V) claimed that the company is the owner of the coffee trademark and the trademark has been registered internationally under the name Gayo Mountain Coffee. ${ }^{[9]}$

The protection of geographical indication is given to Indonesian typical products to prevent them from being registered as overseas brands, as previously happened in the case of Toraja Arabica coffee registered by the Japanese company and the Gayo coffee by the Dutch company. In addition to coffee, there are other Indonesian products that need to be protected through geographical indications, such as nutmeg from the Banda Islands, Nilam from Aceh, and Bilih Fish from Lake Singkarak before they are claimed by other countries. With the foreign trademark registration, the products harvested from the land of Indonesia can no longer be recognized as belonging to Indonesia because they can hardly be claimed to have come from Indonesia and it is the foreign parties that will enjoy the benefits of the famous Indonesian products. ${ }^{[10]}$

The law should provide solutions to various problems arising in relation to the intellectual property rights. The law should be able to protect the intellectual works in order to develop the people creativity which ultimately leads to the goal of successful intellectual property protection. ${ }^{[11]}$

The geographical indication is very important because it serves as a sign indicating the origin of an item which, due to geographic environmental factors including natural factors, human factors, or a combination of these two factors, gives certain characteristics and qualities. 


\section{Problem}

The problem in this study: how can Geographical Indications as part of the intellectual property rights be legally protected?

\section{Research method}

This research applied a normative legal approach. A normative legal method is a legal research that treats law as a norm system. The data was secondary data consisting of: a) primary legal materials in the form of legislation; $b$ ) secondary legal materials in the form of writings, both in the form of books and articles containing comments or analysis related to the subject matter; c) tertiary legal materials in the form of dictionaries. The data was collected using a literature review and document analysis. The data was analyzed using a qualitative method based on deductive reasoning.

\section{Discussion}

Geographical indication was initially unknown in Indonesia's legal terminology. This term emerged from the inclusion of the Trademark Law No. 15 of 2001 adopted from Article 22 to 24 of The Agreement on Trade Related Aspects of Intellectual Property Rights (TRIPs Agreement). The definition of geographical indication by law is a sign indicating the origin of an item and/or a product which, due to geographical factors including natural factors, human factors or a combination of these two factors, gives reputation, quality, and certain characteristics to the product and/or item. (Law No. 20 of 2016 Article 1 Paragraph (6)). Soon after Indonesia ratified the convention - which was the outcome of the 1994 World Trade Organization (WTO) agreement in Marrakech, all laws and regulations regarding Indonesian intellectual property rights, including trademarks, were formulated in accordance with the TRIPs Agreement. The clauses on geographical indication are placed in Articles of the Trademark Law No. 15 of 2001.

After including the clauses of geographical indication, Indonesia began to identify, record and list the domestic products that have a potential for a geographical indication. The universities start to perform various researches and scientific works related to geographical indication. Almost all provinces in Indonesia conducted studies on goods and handicraft products that have a potential for geographical indications and the research findings were then recorded and archived at various university libraries. However, only a small number of the research results was registered at the Directorate General of Intellectual Property of the Ministry of Law and Human Rights of the Republic of Indonesia to obtain a legal certainty or certification.

In response to the Article on geographical indications in the Trademark Law, the Government issued a Government Regulation (PP) No. 51 of 2007 which technically regulates matters pertaining to geographical indications. Indonesia is one of the countries that signed the agreement on the establishment of the World Trade Organization. Inside the WTO, there are provisions of the TRIPs (Trade Related Aspects of Intellectual Property Rights) which regulate Intellectual Property Rights and ratify the agreement through Law Number 7 of 1994 on Legalization of Agreement on WTO establishment, which was enacted on 2 November 1994. One form of the Intellectual Property Right protections in the TRIPs Agreement is the geographical indication as set forth in Articles 22 to 24.

In the Indonesian system of Intellectual Property Rights, geographical indications are part of the trademark law. Geographical indication is the concept of Intellectual Property Rights that indicates the origin of a product in relation to the quality, characteristics, and reputation 
of the product. Geographical indications show the relationship between goods, place of origin, quality and characteristics of the goods. The quality and characteristics of the product are related to the place where the product is originally generated. Another term used to protect products from a region is Original Indication (Designation of Origin). The difference between geographical indication and original indication is that the original indication only shows the origin of an item without displaying any characteristics or superiority of the item. In contrast, geographical indication shows not only the origin of a product, but also demonstrates the characteristics and advantages of the product in comparison to other similar items.

Geographical indication is a sign indicating the origin of an item and/or a product which, due to geographical environmental factors including natural factors, human factors or a combination of both factors, gives reputation, quality and certain characteristics to the products and/or goods. ${ }^{[12]}$ Thus, the reputation of quality and specific characteristics are generated by the presence of the geographical factors. ${ }^{[13]}$

Based on the definition, there are two main points referring to geographical indication, namely a sign indicating the origin of an item and/or a product due to geographical environmental factors and the generated items and/or products have certain characteristics.

The sign, as referred to in the geographical indication, may come in the form of a label placed on the goods. It may also be the name of a region or area, word, image, letter or a combination of such elements. While the goods and/or products possessing certain characteristics can be in the form of agricultural products, processed products, handicrafts, or other processed products which have the characteristics of the region. ${ }^{[14]}$

Actually, geographical indication has its own characteristics that make it distinctive from other products. The characteristics of geographical indications include: first, Geographical indications can be requested by institutions representing communities living in the areas which produce natural products or natural resources; manufacturers of agricultural goods; makers of handicraft or industrial products; the merchant who sells the goods, the agency authorized to do so or the consumer group. Second, the exclusive right to geographical indication is not regulated and this logically means that there is no time limit for the right owner of the geographical indication.

The protection of intellectual property rights will be closely linked to aspects of science, technology and economics. ${ }^{[15]}$ However, the protection of geographical indications is different from other intellectual property protection. The protection of intellectual property rights is generally individual, but the protection of geographical indications is collective in the sense that the protection is given to a product manufactured in a particular area and is requested by the community group or the provincial or district/city government in the area where the goods/products are generated.

Protecting geographical indication has a great economic value and benefits for the place of origin. The area can be popular both nationally and internationally. New geographical indication will get a protection only if it is already registered. Learning from European countries, geographical indication products can provide substantial benefits to the economy of the country. Wine sales in France rose about $230 \%$ of its sales to other countries. Cheese sales grew between $158-203 \%{ }^{[16]}$ The sales of the local Florida oranges from the American State of Florida, which is widely known for its typical taste, was amounted to 9 million US Dollars as well as opening about 80,000 new jobs and expanding 230,670 hectares of land. ${ }^{[17]}$

The benefits of the existing potential can be attained if countries (including Indonesia) can protect their typical products with the protection system of geographical indications. From this point on, the protection of international geographical indications is deemed necessary. With an international protection, some benefits can be gained as follows: first, geographical indication protection can be used as a product marketing strategy at domestic and international trade levels. Second, it adds value to the product and improves the 
producer's welfare. Third, it improves the reputation of geographical indication products at international trade level. Fourth, equality of treatment as a result of promotion from abroad, and fifth, geographical indication protection acts as a tool to avoid fraudulent competitions.

Geographical indication protection aims at protecting uniqueness from counterfeiting acts or unnecessary use while providing opportunities and protection for the community living in the region of the typical product to obtain maximum benefits from that particular product. In addition, the protection of geographical indication is also beneficial for the consumer as it provides product quality assurance. ${ }^{[18]}$

\section{Conclusions}

Geographical indication certainly requires a legal protection. With such protection, the natural rights owned by the right holder can be guaranteed and a sense of security can be realized. A product yielded from the nature and human creativity with certain distinctive characteristics, cannot be found elsewhere, and has a reputation that can increase the competitive advantage of a region, should get more attention from the government, especially the local government. The legal protection of geographical indication not only provides economic benefits to the right holder, but also to the geographical environment where the product is originally generated.

\section{References}

1. Adolf, Dasar-dasar hukum kontrak internasional, (Refika Aditama, Bandung, 2007).

2. U.H. Sanjaya, Problematik penerapan undang-undang hak kekayaan intelektual tentang indikasi geografik pada undang-undang merek, Jurnal Panorama Hukum Vol.1 (2), (2016).

3. Sudarmanto, kepentingan negara berkembang terhadap hak atas indikasi geografis, sumber daya genetika dan pengetahuan tradisional, (Lembaga Pengkajian Hukum Internasional Fakultas Hukum Universitas Indonesia, Jakarta, 2005).

4. O.K. Saidin, Aspek hukum hak kekayaan intelektual (intellectual property rights), (Raja Grafindo, Jakarta, 2015).

5. B.A. Riswandi and M. Syamsudin, Hak kekayaan intelektual dan budidaya hukum, (Raja Grafindo Persada, Jakarta, 2004).

6. T.S. Utomo, Hak kekayaan intelektual (HKI) di era global sebuah kajian kontemporer, (Graha Ilmu, Yogyakarta, 2010).

7. S. Margono, and A. Angkasa, Komersialisasi aset intelektual aspek hukum bisnis, (Grasindo, Jakarta, 2002).

8. I. Rahmatullah, Perlindungan indikasi geografis dalam hak kekayaan intelektual (HKI) melalui ratifikasi perjanjian Lisabon, Jurnal Citra Hukum Vol.1 (2), (2014)

9. S. Mawardi, Establishment of geographical indication protection system in Indonesia, case in coffee, Worldwide Symposium on Geographical Indications jointly orginized by the World Intellectual Property Organization (WIPO) and the Patent Office of the Republic of Bulagaria, Sofia, June 10 - 12, (2009).

10. A. Sutedi, Hak atas kekayaan intelektual, (Sinar Grafika, Jakarta, 2009) 
11. N. Anggraeni, perlindungan terhadap indikasi geografis (produk yang disertai nama tempat) dalam kerangka hukum nasional dan hukum internasional, Tesis Hukum, (2013).

12. A. Muhammad, Hak ekonomi hak kekayaan intelektual, (PT Citra Aditya Bakti, Bandung, 2001).

13. E. Purwaningsih, Perkembangan hukum intellectual property rights, (Ghalia Indonesia, Bogor, 2005).

14. M. Djumhana, Djubaedillah, Hak milik intelektual sejarah, teori dan prakteknya di Indonesia, (PT Citra Aditya Bakti, Bandung, 2003).

15. A.M. Ramli, Hak atas kepemilikan intelektual teori dasar perlindungan rahasia dagang, (CV. Mandar Maju, Bandung, 2000).

16. J.A. Clarke, The public policy objectives of geographical indications, Worldwide Symposium on Geographical Indications, Lima 22-24 June (2011).

17. K. Keck, Florida orange juice healthy, pure and simple, Worldwide Symposium on Geographical Indications, Lima, 22-24 June (2011).

18. A. Miru, Hukum merek cara mudah mempelajari undang-undang merek, (PT Raja Grafindo Persada, Jakarta, 2005). 